\title{
Variation in Seedling Growth of Tamarindus indica (L.): A Threatening Medicinal Fruit Tree Species in Bangladesh
}

\author{
Md. Salim Azad, ${ }^{1,2}$ Nurun Nahar, ${ }^{1}$ Abdus Subhan Mollick, ${ }^{1,3}$ and Md. Abdul Matin ${ }^{1}$ \\ ${ }^{1}$ Forestry and Wood Technology Discipline, Khulna University, Khulna 9208, Bangladesh \\ ${ }^{2}$ Faculty of Forest Science and Forest Ecology, Georg-August University, Goettingen, Germany \\ ${ }^{3}$ Laboratory of Cell and Functional Biology, Faculty of Science, University of the Ryukyus, Okinawa, Japan
}

Correspondence should be addressed to Md. Salim Azad; azadfwt@yahoo.com

Received 7 May 2014; Revised 3 July 2014; Accepted 4 July 2014; Published 23 July 2014

Academic Editor: Ernesto I. Badano

Copyright (C) $2014 \mathrm{Md}$. Salim Azad et al. This is an open access article distributed under the Creative Commons Attribution License, which permits unrestricted use, distribution, and reproduction in any medium, provided the original work is properly cited.

\begin{abstract}
Seedling growth is a precondition for conservation and sustainable use of genetic resources which depends upon understanding of breeding system, genetic inconsistency, and evolutionary forces in forest tree improvement. The aim of this study was to determine variation in seedling growth and age-age correlations of Tamarindus indica at population level in Bangladesh. The study revealed significant $(P<0.05)$ differences of seasonal variation in seedling growth. Height and collar diameter growth showed significant $(P<0.05)$ positive correlation with mean monthly rainfall. The study also revealed significant difference $(P<0.05)$ of seedling growth among T. indica population. PCA illustrated rainfall, height growth, and diameter growth as the main characters in this study which defined drought as an additive character for this species. Cluster analysis of similarity showed how seedlings from $22.67^{\circ} \mathrm{N}$ latitude (origin) separated from others. An increasing trend of age-age correlation was identified in both cases of shoot height and diameter growth. The study concluded that seed collection for either ex situ conservation or seedling production can be done from $22.67^{\circ} \mathrm{N}$ latitude as seedlings from that area performed better than others, and early clonal selection of $T$. indica can be done at the age of 9 months.
\end{abstract}

\section{Introduction}

Tamarindus indica (Linn), a multipurpose, leguminous, tropical evergreen fruit tree species of Caesalpiniaceae subfamily, is indigenous to Africa (Madagascar, Zimbabwe, Chad, Sudan, Nigeria, Uganda, and Kenya) and Southern Asia which plays an important role in ecological and economic services [1-4]. Domestication of this species in south-east Asian countries like India, Sri Lanka, Nepal, Pakistan, and Bangladesh is very advanced [3-5] and it is also practiced in Australia, Brazil, Mexico, Philippines, America, and Jamaica [1]. T. indica is found in semiarid areas of tropics up to $1500 \mathrm{~m}$ above sea level where annual rainfall is more than $1500 \mathrm{~mm}$ and can grow well on poor soil especially in degraded areas $[4,6]$. The most important product of $T$. indica is the pulp of the fruit, and this species is well accepted for its soft, juicy, appetizing, tasty, delicious fruit because of its brown, sticky, sour-sweet pulp generally used as an ingredient in curries, chutneys, preserves, pickles, sherbets, and beverages in a variety of dishes and drinks in household as well as in confectionery $[1,3,4,7]$. The fruits of this species contain high levels of protein, carbohydrate, minerals (potassium, phosphorus, and calcium), and iron with low amount of water content [8]. Tamarind is also documented as a fodder species. The seeds and the leaves can be used for the nourishment of household animal [9]. The leaves, bark, seed, and roots of tamarind are also documented as a source of allelopathic substance for the weed crops [1012]. The roots of tamarind have allele-chemical capability and, thus, contribute significantly to a weed free environment around the tamarind tree [11]. By the application of powder of leaves, barks, and seeds of this species to the agricultural field, farmer can reduce nutrient and water competition to the plants $[10,12]$. Medicinal value of tamarind is also found to reduce fever and to cure intestinal ailments. It is used as a popular ingredient of cardiac and blood sugar reducing medicines. Antioxidant, anti-inflammatory, antimicrobial, anti-snake venom properties, and antifungal activity have 
been documented in many research reports [13-15]. It is also useful against scurvy. T. indica andcan play an important role in mitigating the fuel wood crisis of Bangladesh as it has high calorific value. It also plays roles in erosion control through cultivating in degraded land [4]. Home gardeners and tree planters have already planted this species in different localities of Bangladesh and have proved as a successful tree species because of its growth and specially its ability to thrive in poor soil. As an attractive, valuable, and useful tree, this species can be considered for massive plantation because of potential nitrogen fixation ability, tolerance to infertile, acid, alkaline, saline, or seasonally waterlogged soil [1]. Farmer's choice should be given preference in selecting species for tree cultivation $[4,16,17]$. T. indica is commonly and comprehensively cultivated in public and private plantation programs in Bangladesh [18]. It is very much imperative to introduce this species all over the country particularly in homestead and in fallow lands as we have severe scarcity of timber and fuel wood in Bangladesh. T. indica can be an alternative to meet the requirements of fuel wood, poles, and timber $[4,17]$.

Understanding of breeding system, genetic inconsistency, and evolutionary forces are the preconditions for any tree improvement program [19]. Conservation and sustainable use of genetic resources depend upon such information. Genetic variation among population is expected due to environmental variation of natural range of the species [20, 21]. Provenance trial of native species is desirable to screen the genetic and environmental components of phenotypic inconsistency among trees from different seedlings origins for utmost productivity in production forestry [19, 21-23]. Several studies explained the correlations of seed germination and seedling growth variables with origins of the plants in many tropical tree species [17, 19]. Growth analysis showed significant variation in height and diameter growth in various tropical species [24-26]. Genetic variation in height and diameter growth among $T$. indica populations are expected, since environmental factors may vary extensively within natural range of the species. The genetic variation among population can, consequently, be recognized by provenance research and exploited through selection of superior population for seed collection and mass propagation for conservation [21]. Seed source variation and presowing treatment effect can influence seed germination of T. indica [4] but their effect on seedling growth is still unknown. Seasonal variation can also influence seedlings growth between species [27]. There are very few documents available on seed germination of Tamarindus indica $[4,13]$. Until now, no information is available on seedling growth due to variation of seedling origins, presowing treatment effect, and seasonal effect which make optimum scheduling of nursery operations difficult. Therefore, an attempt has been made to carry out the study. We hypothesize that seedling growth may vary throughout the study period due to seasonal variation. We also hypothesize that height and diameter growth varies among T. indica population due to genetic variation. The objectives of the study are (i) to examine the monthly seedling growth; (ii) to determine seedling growth variation among $T$. indica population at the nursery stages; and (iii) to establish age-age

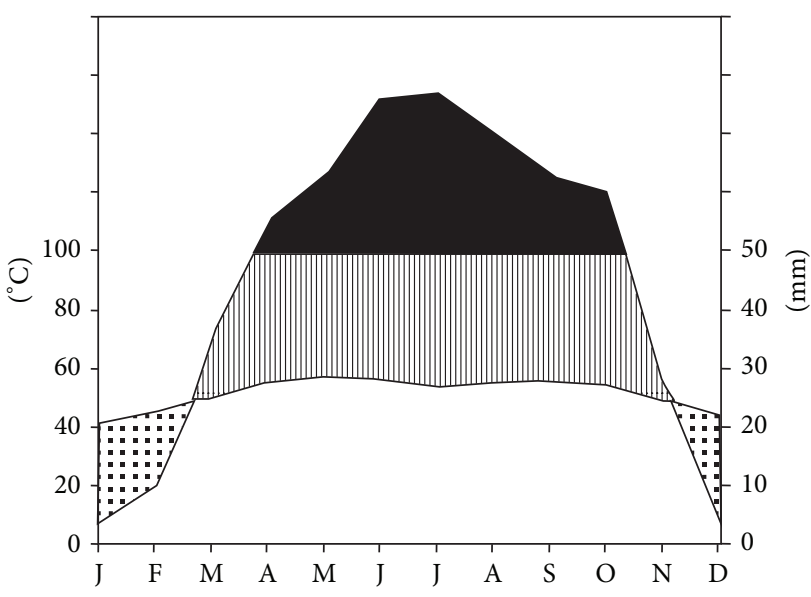

FIGURE 1: Climatic diagram of mean monthly temperature and rainfall throughout the study period.

correlation for early selection procedure for conservation and sustainable use of genetic resources which will help in tree improvement programme.

\section{Materials and Methods}

2.1. Study Area. An experiment of seedling growth of tamarind was conducted in the forest nursery of Forestry and Wood Technology Discipline, Khulna University, Bangladesh. The study area is situated in the south-western part of Bangladesh near the Sundarbans, the largest continuous mangrove forest in the world. The location of the study area is $22.802^{\circ} \mathrm{N}$ and $89.533^{\circ} \mathrm{E}$ and it is about $4 \mathrm{~m}$ above the sea level.The climate of the locality is recognized as subtropical in nature, especially winter (NovemberFebruary), summer (March-mid June), and monsoon (late June-September) are the distinguishing seasons, almost similar to the other regions of the country. The temperature fluctuation in winter is very low between 7 and $12^{\circ} \mathrm{C}$ and it rises from $25^{\circ} \mathrm{C}$ to $32^{\circ} \mathrm{C}$ in summer except that very seldom it might be increased up to $40^{\circ} \mathrm{C}$. Figure 1 describes mean monthly temperature and rainfall throughout the experiment in the study site. Satkhira, Khulna, and Bagerhat, the seedlings' origins (seed source locations) occupy an extensive area of tidal floodplain agroecological zone. A considerable portion of Satkhira district represents acid sulphate soil. Soil $\mathrm{pH}$ of this area is strongly acidic ranging from 2.9 to 4.0, whereas the general soil types of Khulna and Bagerhat districts are noncalcarious grey floodplain soil and calcarious dark grey floodplain soils. Soil pH of Bagerhat is mostly acidic to neutral having a range of 5.5-7.3, whereas soil pH of Khulna is almost similar with Bagerhat but a considerable portion falls under moderately alkaline ranging from 7.3 to 8.4. The seed source location Rajshahi belongs to an old alluvial formation, which is usually composed of massive argillaceous beds of pale reddish brown; the soil is deficient in lime, nitrogen, and phosphorous. Soil $\mathrm{pH}$ varies from 6 to 6.5. On the other hand, seed source location Jessore belongs to riverline lands of Gangetic plains. The soils are 
TABLE 1: Different seedling origins of Tamarindus indica in Bangladesh with latitude and longitude and number of seeds used for the experiment.

\begin{tabular}{lccc}
\hline Seedlings origin $(*)$ & Latitude & Longitude & Number of seeds \\
\hline L1: Satkhira (Sat) & $22.35^{\circ} \mathrm{N}$ & $89.08^{\circ} \mathrm{E}$ & 240 \\
L2: Rajshahi (Raj) & $24.37^{\circ} \mathrm{N}$ & $88.60^{\circ} \mathrm{E}$ & 240 \\
L3: Norail (Nor) & $23.13^{\circ} \mathrm{N}$ & $89.50^{\circ} \mathrm{E}$ & 240 \\
L4: Khulna (Khu) & $22.82^{\circ} \mathrm{N}$ & $89.55^{\circ} \mathrm{E}$ & 240 \\
L5: Bagerhat (Bag) & $22.67^{\circ} \mathrm{N}$ & $89.80^{\circ} \mathrm{E}$ & 240
\end{tabular}

Note: $(*)$ indicates abbreviation of location.

rich and are characterized by high lime content. The soil $\mathrm{pH}$ varies from 7 to 8.4 .

2.2. Plant Materials and Design of the Experiment. Prior to the start of the study of seedling growth of T. indica, an experiment of seed source variation and presowing treatment effect on seed germination was carried out [4]. The seeds were collected from different locations (Satkhira, Rajshahi, Norail, Khulna, and Bagerhat) of Bangladesh (Table 1) and treated with four presowing treatments, that is, treatment (1) control, treatment (2) immersion in cold water $\left(4^{\circ} \mathrm{C}\right)$ for $24 \mathrm{~h}$, treatment (3) immersion in hot water $\left(80^{\circ} \mathrm{C}\right)$ for $10 \mathrm{~min}$, and treatment (4) scarification with sand paper [4]. One seed was sown in each poly bag $(10 \mathrm{~cm} \times 15 \mathrm{~cm})$. The medium of the poly-bags was mixture of topsoil and cow dung in the ratio of $3: 1$. Poly bags were kept in shade throughout the experiment. The seeds were sown at a depth of $0.5-1.5 \mathrm{~cm}$ and watering was done manually once a day. Randomized block design (RBD) with three replications was used for the experiment. A number of $300(5 \times 3 \times 20)$ poly bags were used for each treatment of five different seed sources. Therefore, the total numbers of poly bags were $1200(4 \times 5 \times 3 \times 20)$ used for seed germination.

2.3. Measurements. At the end of seed germination, seedling growth performances (collar diameter and shoot height of the plant) were measured for twelve months. Collar diameter of the plant was measured using electronic digital caliper in $\mathrm{mm}$ (150 mm, accuracy $\pm 0.02 \mathrm{~mm}$, LR44, 2006/66/EC). Height of the plant was measured using centimeter scale (in $\mathrm{cm}$ ).

2.4. Data Analysis. General linear model (GLM) procedure of STATISTICA software (version 10) was employed for analysis of variance (ANOVA). ANOVA for monthly growth variation on collar diameter and height was based on the following fixed effect model:

$$
y_{i j}=\mu+S_{i}+\varepsilon_{i j}
$$

where $y_{i j}$ is seedling growth (collar diameter and height) of $j$ th replication of the $i$ th months, $\mu$ is the overall mean, $S i$ the effect due to $i$ th month $(i=1,2,3, \ldots, 12)$, and $\varepsilon_{i j}$ is the error. For variation of seedling origins (seed sources) and presowing treatment effect on seedling growth (collar diameter and height), two-way ANOVA was performed based on the linear model expressed as

$$
y_{i j l}=\mu+L_{i}+T_{j}+(L T)_{i j}+\varepsilon_{i j l},
$$

where $y_{i j l}$ is seedling growth of $l$ th replication of the $i$ th location (seedling source, $i=1,2, \ldots, 5$ ) and $j$ th treatment $(j=1,2, \ldots, 4), \mu$ is the overall mean, $(L T)_{i j}$ the interaction effect of seed source and presowing treatment, and $\varepsilon_{i j l}$ is the error. The means monthly growth variation, variation due to seedlings origins, and presowing treatment effect on seedling growth (collar diameter and height) which exhibited significant differences were compared using Tukey's test at the $5 \%$ level. Pearson correlations matrix was calculated to check the relationships between geoclimatic data and seedling growth performance. For this purpose, the mean value of each character for each location was used. Age-age correlation was also calculated to establish an early selection procedure for conservation and sustainable use of genetic resources which will help in tree improvement program. Data were also subjected to principal component analysis (PCA) and cluster analysis. Principal component analysis (PCA) was carried out to find out important components which were correlated with other underlying variables of seedling growth of $T$. indica and environmental factors of the localities (seedling origins). Origin of seedlings similarities were measured using PAST software [28] through calculating Bray-Curtis similarity index based on shoot height and collar diameter. The scale of the similarity index is $0-1$. The value of the index is " 0 " when there is no similarity among the seedling origins and the value of the index is " 1 " when the seedling origins are completely similar.

\section{Results}

In our previous paper, we discussed seed germination and found that there was significant difference of presowing treatment effect on seed germination but no significant difference of seed source variation on seed germination [4].

3.1. Height Growth. Height growth of the seedlings T. indica which originated from five different locations of Bangladesh, treated with four presowing treatments was measured at nursery stage during 12 months of the study (Figure 2). The result revealed that height growth was comparatively slow during October to May and then it started growing rapidly. Analysis of variance (ANOVA) showed significant difference $(P<0.05)$ of monthly growth on height during the experiment. Tukey's HSD test revealed that the mean monthly variation on height exhibited significant difference $(P<0.05)$ at all cases except the growth in December-January $(P>$ $0.05)$ and March-April $(P>0.05)$. Analysis of variance also showed significant difference $(P<0.05)$ of seedling origins and treatment variation on height growth during the experiment. But there was no significant difference $(P>$ 0.05 ) of interaction between seedling origins and treatment variation. Tukey's HSD test revealed that height growth significantly $(P<0.05)$ defer from seedlings originated from the seed of $22.67^{\circ} \mathrm{N}$ latitude treated with control to the 


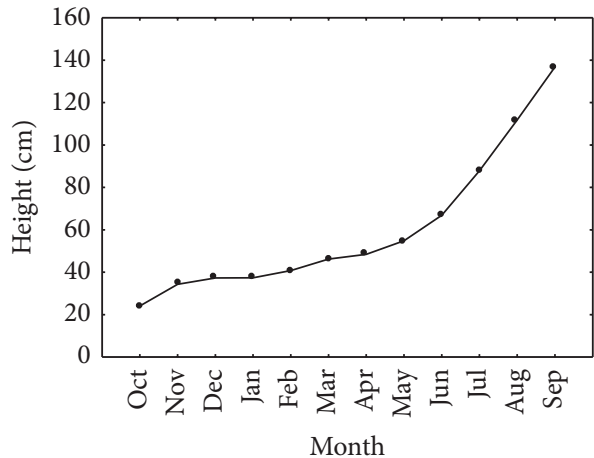

(a)

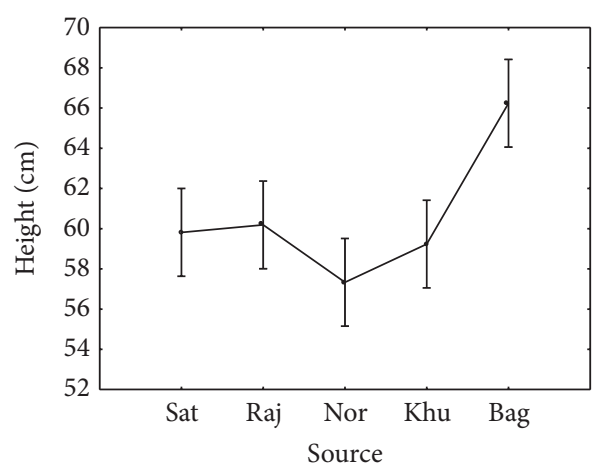

(c)

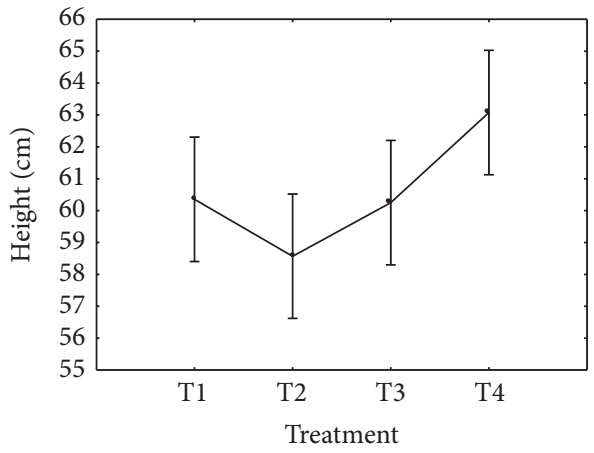

(e)

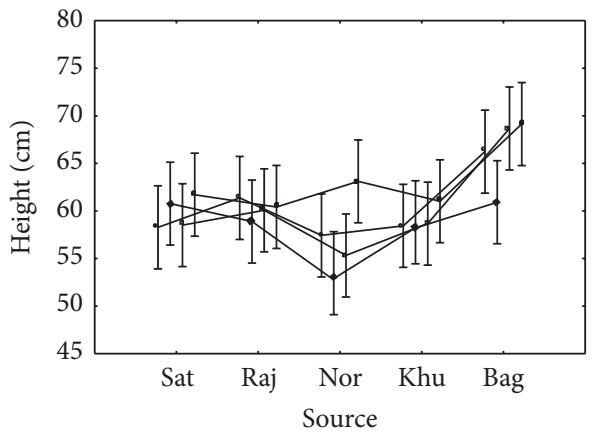

$$
\begin{array}{ll}
\equiv \mathrm{T} 1 & \text { ㅍ } \mathrm{T} 3 \\
\text { ॠ } 2 & \text { झ } \mathrm{T} 4
\end{array}
$$

(g)

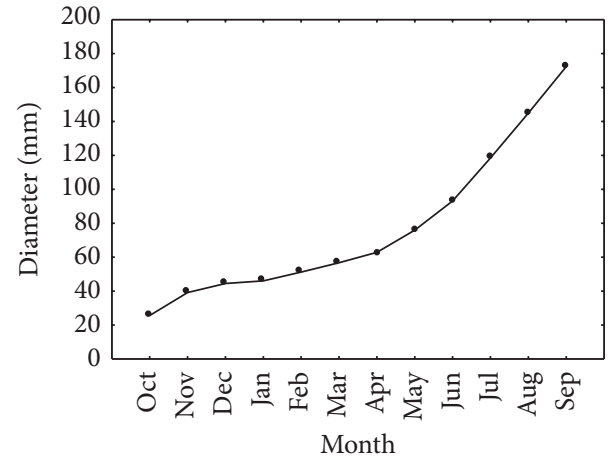

(b)

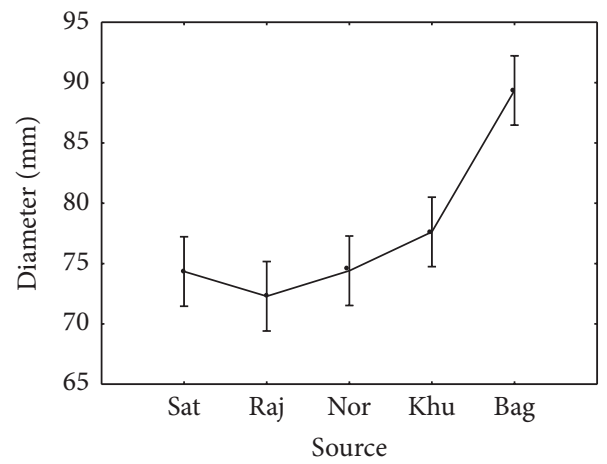

(d)

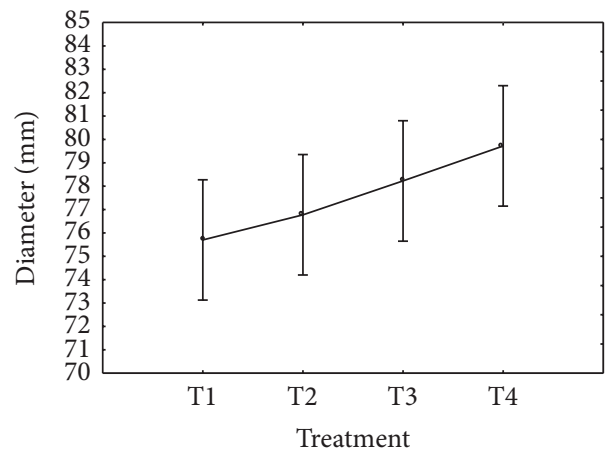

(f)

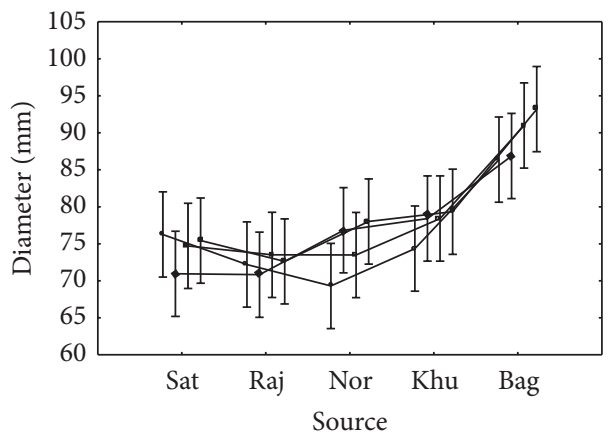

$$
\begin{array}{ll}
\text { 프 } \mathrm{T} 1 & \text { 프 } \mathrm{T} \\
\text { } \mathrm{T} 2 & \text { 프 } \mathrm{T} 4
\end{array}
$$

(h)

FigURE 2: Seedling growth of $T$. indica in relation with (i) month ((a) \& (b)); (ii) seed source ((c) \& (d)); (iii) presowing treatment ((e) \& (f)); and (iv) seed source and treatment interaction ((g) \& (h)). Note: Sat—Satkhira, Raj—Rajshahi, Nor-Norail, Khu—Khulna, Bag-Bagerhat, T1-control, T2-cold water treatment, T3-hot water treatment, and T4-scarification. Vertical bars denote $95 \%$ confidence intervals. 
TABLE 2: Correlations between the particulars of seedling growths and geoclimatic data of T. indica.

\begin{tabular}{lcccccc}
\hline Traits & Diameter & Height & Rainfall & Temperature & Latitude & Longitude \\
\hline Diameter & 1 & & & & & \\
Height & 0.0035 & 1 & & & & \\
Rainfall & 0.0063 & $0.6560^{*}$ & 1 & & & \\
Temperature & 0.0077 & 0.1998 & $0.4595^{*}$ & 1 & 1 & 1 \\
Latitude & -0.0074 & -0.0136 & -0.0002 & 0.0002 & $-0.6806^{*}$ & 1 \\
Longitude & 0.0076 & 0.0390 & -0.0001 & 0.0001 & \\
\hline
\end{tabular}

Marked $(*)$ correlations are significant at $P<0.05$.

seedling originated from the seed of $23.13^{\circ} \mathrm{N}$ latitude treated with cold water $\left(4^{\circ} \mathrm{C}\right.$ for 24 hours); seedlings originated from the seed of $22.67^{\circ} \mathrm{N}$ latitude treated with hot water $\left(80^{\circ} \mathrm{C}\right.$ for $\left.10 \mathrm{~min}\right)$ to the seedling originated from the seed of $23.13^{\circ} \mathrm{N}$ latitude treated with control; seedlings originated from the seed of $22.67^{\circ} \mathrm{N}$ latitude treated with sand paper scarification to the seedling originated from the seed of $23.13^{\circ} \mathrm{N}$ latitude treated with cold water $\left(4^{\circ} \mathrm{C}\right.$ for 24 hours); seedlings originated from the seed of $22.67^{\circ} \mathrm{N}$ latitude treated with hot water $\left(80^{\circ} \mathrm{C}\right.$ for $\left.10 \mathrm{~min}\right)$ to the seedling originated from the seed of $23.13^{\circ} \mathrm{N}$ latitude treated with cold water $\left(4^{\circ} \mathrm{C}\right.$ for 24 hours); seedlings originated from the seed of $22.67^{\circ} \mathrm{N}$ latitude treated with sand paper scarification to the seedling originated from the seed of $23.13^{\circ} \mathrm{N}$ latitude treated with cold water $\left(4^{\circ} \mathrm{C}\right.$ for 24 hours); seedlings originated from the seed of $22.67^{\circ} \mathrm{N}$ latitude treated with hot water $\left(80^{\circ} \mathrm{C}\right.$ for $10 \mathrm{~min}$ ) to the seedling originated from the seed of $23.13^{\circ} \mathrm{N}$ latitude treated with hot water $\left(80^{\circ} \mathrm{C}\right.$ for $\left.10 \mathrm{~min}\right)$; seedlings originated from the seed of $22.67^{\circ} \mathrm{N}$ latitude treated with sand paper scarification to the seedling originated from the seed of $23.13^{\circ} \mathrm{N}$ latitude treated with hot water $\left(80^{\circ} \mathrm{C}\right.$ for $\left.10 \mathrm{~min}\right)$.

3.2. Diameter Growth. Diameter growth of the seedlings of $T$. indica which originated from five different locations of Bangladesh, treated with four presowing treatments was also measured at nursery stage during 12 months of study (Figure 2). The result revealed that diameter growth showed similar pattern like height growth. The growth was relatively slow during October to May and then it started quickly. Analysis of variance showed significant difference $(P<$ 0.05 ) of monthly growth on diameter during the experiment. Tukey's HSD test revealed that the mean monthly growth variation on diameter exhibited significant difference $(P<$ $0.05)$ at all cases except the growth in December-January $(P>0.05)$. Analysis of variance also showed significant difference $(P<0.05)$ of seedling origins on collar diameter growth but there was no significant difference $(P>0.05)$ of treatment variation and interaction between seed source and treatment variation on diameter growth during the experiment. Tukey's HSD test revealed that diameter growth significantly $(P<0.05)$ defer from seedlings originated from the seed of $22.67^{\circ} \mathrm{N}$ latitude to the seedling originated from other seed sources. But there was no significant difference $(P>0.05)$ of diameter growth of seedlings originated from the seed of $22.35^{\circ} \mathrm{N}$ latitude to the seedling originated from the seed of $24.37^{\circ} \mathrm{N}$ latitude; seedlings originated from the seed of $22.35^{\circ} \mathrm{N}$ latitude to the seedling originated from the seed of $23.13^{\circ} \mathrm{N}$ latitude; seedlings originated from the seed of $22.35^{\circ} \mathrm{N}$ latitude to the seedling originated from the seed of $22.82^{\circ} \mathrm{N}$ latitude; seedlings originated from the seed of $24.37^{\circ} \mathrm{N}$ latitude to the seedling originated from the seed of $23.13^{\circ} \mathrm{N}$ latitude; seedlings originated from the seed of $24.37^{\circ} \mathrm{N}$ latitude to the seedling originated from the seed of $22.82^{\circ} \mathrm{N}$ latitude; seedlings originated from the seed of $23.13^{\circ} \mathrm{N}$ latitude to the seedling originated from the seed of $22.82^{\circ} \mathrm{N}$ latitude.

3.3. Relationship between Geoclimatic Data and Seedling Growth Performance. Correlation coefficient $(r)$ along with all probable combinations of variable "height growth" and "diameter growth" with geoclimatic data was summarized in Table 2. Within the growth variables, height growth showed a significant positive correlation $(P<0.05)$ with rainfall, but there was no significant correlation $(P>0.05)$ between height growth and either diameter growth, temperature, or geographic location (latitude and longitude) of the seedling origins. Diameter growth also showed no significant correlation $(P>0.05)$ between diameter growth and either temperature or geographic location (latitude and longitude) of the seedling origins (Table 2).

3.4. Age-Age Correlation. The age-age correlation values $(r)$ with all possible combinations of variable height growth and diameter growth at 3-, 6-, 9-, and 12-month-old seedlings of $T$. indica were summarized in Table 3 . The correlations between $\mathrm{Ht} 12$ and either $\mathrm{Ht} 3, \mathrm{Ht} 6$, or $\mathrm{Ht} 9$ revealed increasing significant correlation $(P<0.05)$. Ht12 and Ht9 showed the highest positive significant correlation $(r=0.8334$ and $P<0.05)$. The correlations between D12 and either D3, D6, or D9 revealed increasing and significant correlation $(P<0.05)$ except the correlation between D12 and D3 $(P>0.05)$. D12 and $\mathrm{D} 9$ showed the highest positive significant correlation $(r=0.8028$ and $P<0.05)$.

3.5. Principal Component Analysis. Principal component analysis (PCA) of the present study of height growth and collar diameter growth showed $\mathrm{PCl}$ contributed to an appreciable variance $(46.01 \%)$ and the difference of eigenvalue between PC 1 (2.76) and PC 2 (1.68) was quite high. Temperature, rainfall, height growth, and collar diameter growth were positively correlated with PC 1 (Figure 3 ). On the other 
TABLE 3: Age-age correlations between traits at 3, 6, 9, and 12 months of T. indica.

\begin{tabular}{lccccccc}
\hline Traits & Ht3 & Ht6 & Ht9 & Ht12 & D3 & D6 & D9 \\
\hline Ht3 & 1 & & & & & \\
Ht6 & $0.6255^{*}$ & 1 & & & & \\
Ht9 & $0.5088^{*}$ & $0.7808^{*}$ & 1 & & & \\
Ht12 & $0.4881^{*}$ & $0.6011^{*}$ & $\mathbf{0 . 8 3 3 4}^{*}$ & $\mathbf{1}$ & & \\
D3 & $0.4056^{*}$ & 0.0976 & 0.0256 & 0.0930 & 1 & & \\
D6 & 0.0687 & $0.3340^{*}$ & $0.3659^{*}$ & $0.1671^{*}$ & $0.1390^{*}$ & & \\
D9 & 0.0445 & $0.3846^{*}$ & $0.4483^{*}$ & $0.2133^{*}$ & 0.0345 & $0.7769^{*}$ & 1 \\
D12 & 0.3260 & $0.2778^{*}$ & $0.2943^{*}$ & $0.1428^{*}$ & 0.0814 & $0.5874^{*}$ & $\mathbf{0 . 8 0 2 8}^{*}$ \\
\hline
\end{tabular}

Marked $(*)$ correlations are significant at $P<0.05$.

Note: $\mathrm{Ht}$ and $D$ indicate height and diameter growth at $3,6,9$, and 12 months.

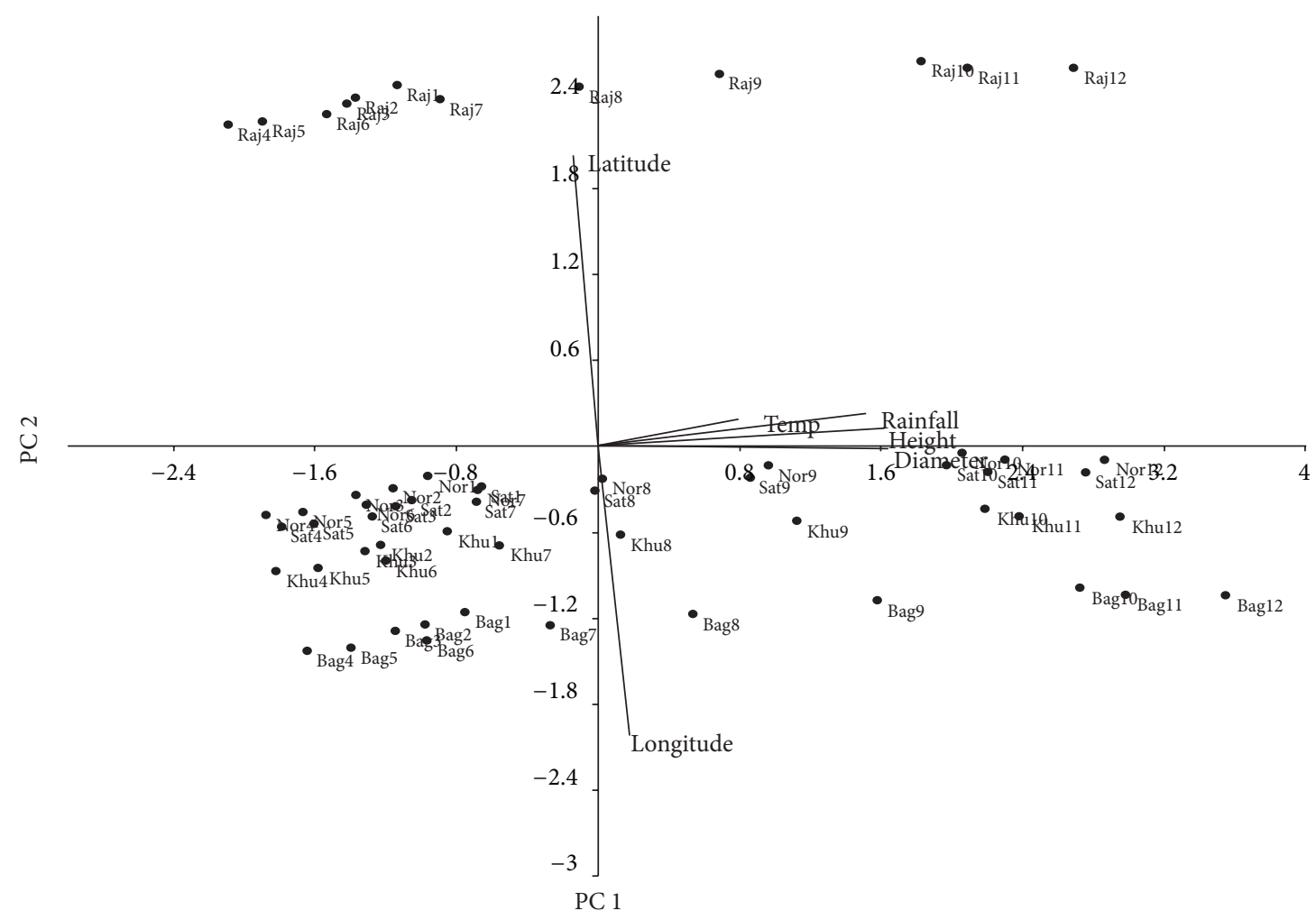

FIGURE 3: Principal component (PC) ordination of height growth and collar diameter growth of seedlings of T. indica originated from different region of Bangladesh with geoclimatic data. The $x$-axis of ordination plot shows PC1 (principal component 1 ) with eigenvalue 2.76 and $46.01 \%$ of total variance of height growth and collar diameter growth and $y$-axis of ordination plot shows PC 2 (principal component 2) with eigenvalue 1.68 and $28 \%$ of total variance of height growth and collar diameter growth. Note: Sat, Raj, Nor, Khu, and Bag are the codes of seedling origin; $1,2,3, \ldots, 12$ are the age of the seedlings.

hand, latitude was positively and longitude was negatively correlated with PC 2 with a variance of $28 \%$.

3.6. Cluster Analysis. Cluster analysis (Figure 4) showed strong similarities among the seedling origin (origin of mother tree) in cases of height growth and collar diameter growth. The dendrogram revealed 2 groupings of seedlings origin based on height growth and collar diameter growth. Seedlings originating from $23.13^{\circ} \mathrm{N}$ (Nor), $22.82^{\circ} \mathrm{N}$ (Khu), $22.35^{\circ} \mathrm{N}$ (Sat), and $24.37^{\circ} \mathrm{N}$ (Raj) latitude were grouping together (Figure 4). In this case, seedlings originating from $22.67^{\circ} \mathrm{N}$ (Bag) latitude were separated with other group. The highest similarities 0.977 (between the seedlings origins Nor and $\mathrm{Khu}$ ) and the lowest similarities 0.924 (between the seedlings origins Nor and Bag) were found in height growth and collar diameter growth.

\section{Discussion}

Distribution of $T$. indica over a wide geographic range [24] making huge range of diversity in edaphic and climatic 


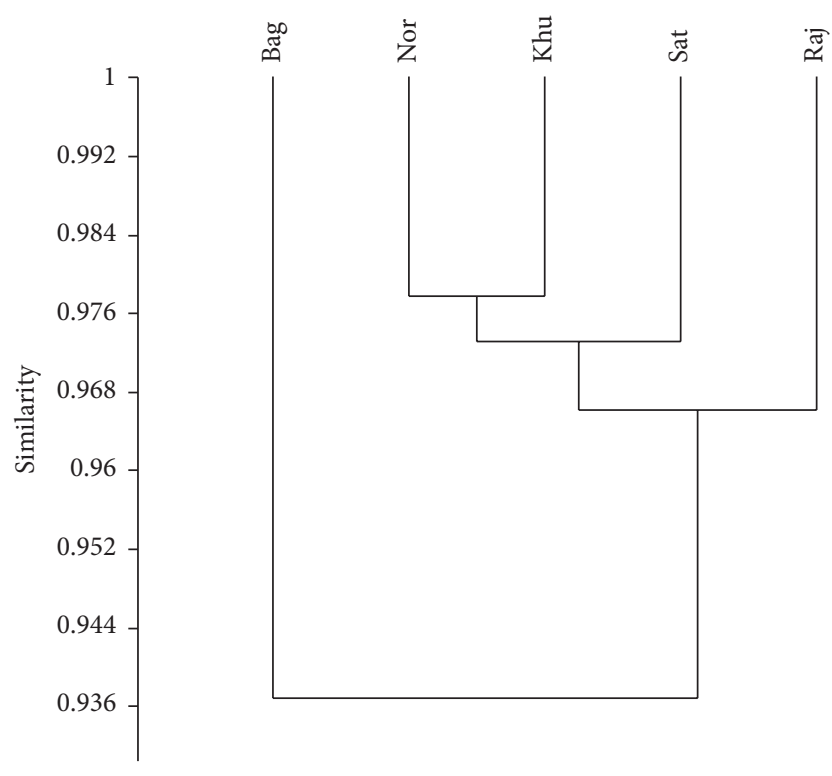

Figure 4: Cluster analysis of Bray-Curtis similarities of seedlings origins of T. indica in Bangladesh based on height growth and presented as dendrogram. Note: Sat-Satkhira, Raj-Rajshahi, NorNorail, Khu-Khulna, and Bag-Bagerhat.

conditions of its surroundings is predictable to be reflected in the genetic contribution of its various populations. Climatic factors, particularly rainfall, either yearly or entirety or in the seasonal allocation, were approximately consistently accompanied by dissimilarity in plant inhabitants [19]. Numerous studies have established huge variations in seedlings growth in response to different environmental conditions (light regime, water availability, and nutrient status) [2931]. In the present study of $T$. indica, a significant seedling growth variation was observed. The study revealed significant difference $(P<0.05)$ of seasonal variation on height growth and collar diameter growth. Sharp height and collar diameter growth of seedlings during the period of JuneSeptember occurred probably due to sufficient precipitation which ensured seedling growth at nursery stages. Matin and Banik [25] discussed similar observations in forest tree seedlings like at nursery stages. Matin and Rashid [26] also found a significant difference of seasonal variation of height growth and collar diameter growth of Albizia tree like at nursery stages. Azad et al. [32] also reported significant difference of seasonal variation of growth performances of Acacia auriculiformis at nursery stages. As the experiment was conducted under similar environment, the variation based on height and collar diameter growth among the seedlings origin may be due to the genotypes. Liu et al. [33] mentioned shoot growth and diameter growth of seedlings are frequently as a consequence of evolved genetic responses to environmental stimuli. Zobel $[34,35]$ discussed about $30 \%$ of total plant genome which is dedicated to seedling growth and development. Krishan and Toky [36] discussed provenance variation of seedling growth of Acacia nilotica in India and found similar result. Rajawat et al. [37] and Kundu and Tigerstedt [19] reported significant provenance variation in seedling growth and survival rates of Azadirachta indica. Loha et al. [21] also discussed significant provenance variation on height growth and collar diameter growth of Cordia africana.

Relationship between height and collar diameter growth showed no significant correlations at nursery stage which suggested that shoot growth and diameter growth did not take place uniformly. Diameter growth reduced when height growth increased which recommended that appearance of inherited characters for collar diameter growth and development was species oriented. Besides these, crowding of seedlings at nursery bed may have a big consequence on collar diameter growth. Collar diameter growth and development appeared to be more susceptible to climatic factors than height. Loha et al. [21] suggested height growth can be much more important at the early stage than diameter growth. Langlois et al. [27] noticed significant correlation between seedlings growth and environmental variables among some conifer tree species. Kundu and Tigerstedt [19] also mentioned correlation between seedlings growth of Azadirachta indica among ten populations and geoclimatic data.

The correlations between growths traits (height growth and collar diameter) were increased from age 3 to 12 months. The increasing trends of the age-age correlations for the both shoot height and collar diameter signify the utilization of any of the juvenile characters for early selection of provenances for further testing. Nevertheless, involving the two juvenile characters, shoot height revealed more positive correlations with more developed character than that of collar diameter. This signifies that shoot height is a superior quantifier of clonal selection than collar diameter. The strong correlations between Ht9 and Ht12 (0.83); D9 and D12 (0.80) recommended that selection of clones 9 month following planting was reasonable for this species. However, Kumar and Singh [38] and Cundall et al. [39] mentioned that the age of early clonal selection should be adequate enough to attain a practical rank of accuracy in selection. Padua [40] reported similar result for Gmelina arborea after 72 months of the experiment. He mentioned that total height at the age of 9 months was feasible for clonal selection for the species. But he suggested that juvenile-mature correlation should be longer than 72 months for a comprehensive perception of clonal performance. Loha et al. [21] also found similar result of an experiment of 8 months for Cordial africana and suggested that early selection should be waited at least one-third of the rotation period for completion of analyzing data. Several authors also reported similar result for several species [39, 41-43].

The outcome of PCA illustrated two separate groups of seedlings origins. PCA not only provided a visual demonstration of the relationship but also indicates which characters were the most vital in defining that relationship. Growth parameters and geoclimatic data were used for PCA analysis. In the present study, mean monthly rainfall, height growth, and collar diameter growth were the most important characters measured in PCA which defined drought as an adaptive trait in demarcation of $T$. indica seedlings originating from localities of Bangladesh. This result was also supported by cluster analysis (Figure 4). Several studies on other species support the present results [19, 21-27]. 
Dendrogram (Figure 4) illustrated clusters of seedlings origins with greater similarities of seedling growth. The seedlings from $22.67^{\circ} \mathrm{N}$ (Ban) were the most distinct from the rest of the seedlings origins because they possessed higher height and collar diameter growth. The seedling origin with similar height and collar diameter growth were positioned together. Since the environmental deviations were negligible for the experiment conducted under similar conditions, the observed growth performances (deviation among the seedlings origin) may be due to genetic reason. Genetic marker analysis of growth traits may provide greater insight to identify genetic variation within and among seedlings origins.

\section{Conclusion}

Evidence from this study indicated that growth parameters vary significantly throughout the year among the seedlings origins of T. indica in Bangladesh. Geoclimatic data were correlated with growth parameters. Among the tested $T$. indica seedlings, seedlings from $22.67^{\circ} \mathrm{N}$ latitude perform better those of others. Though there was no significant relationship between latitude and seedling growth, seed collection for either ex situ conservation or seedling production should be done from that area $\left(22.67^{\circ} \mathrm{N}\right.$ latitude), as they performed better. The existence of very strong age-age correlation between 9 and 12 months suggests huge advantages of early clonal selection. Stem height especially at the age of 9 months, seems to be a better indicator than collar diameter due to higher correlation with 12 months seedlings growth. Based on this information, early clonal selection of T. indica can be done at the age of 9 months.

\section{Conflict of Interests}

The authors declare that they have no conflicts of interest.

\section{Authors' Contribution}

M.D. Salim Azad and M.D. Abdul Matin performed equally in experimental design and paper writing. Nurun Nahar performed data collection and part of data analysis. Abdus Subhan Mollick performed part of data analysis and manuscript editing. Comprehensive data analysis was done by M.D. Salim Azad.

\section{Acknowledgments}

The authors acknowledge the Forestry and Wood Technology (FWT) Discipline, Khulna University, Bangladesh, for providing logistics support during the experiment. The authors thank the staff of the nursery of FWT Discipline, Khulna University, Bangladesh, for providing their help and cooperation during the experiment. The authors also acknowledge the owners of the home garden for their contribution and support during the experiment.

\section{References}

[1] D. K. Das and M. K. Alam, Trees of Bangladesh, Bangladesh Forest Research Institute (BFRI), Chittagong, Bangladesh, 2001.

[2] A. B. Fandohan, A. E. Assogbadjo, R. L. Glèlè, B. Sinsin, and P. van Damme, "Impact of habitat type on the conservation status of tamarind (Tamarindus indica L.) populations in the W National Park of Benin," Fruits, vol. 65, no. 1, pp. 11-19, 2010.

[3] D. Sidibé, H. Sanou, Z. Teklehaima-Teklehaimanot, D. Mahamadi, and S. Koné, "The use of mycorrhizal inoculation in the domestication of Ziziphus mauritiana and Tamarindus indica in Mali (West Africa)," Agroforestry Systems, vol. 85, no. 3, pp. 519-528, 2012.

[4] M. S. Azad, N. Nahar, and M. A. Matin, "Effects of variation in seed sources and pre-sowing treatments on seed germination of Tamarindus indica: a multi-purpose tree species in Bangladesh," Forest Science and Practice, vol. 15, no. 2, pp. 121129, 2013

[5] B. Fandohan, A. E. Assogbadjo, R. Glèlè Kakaï, T. Kyndt, and B. Sinsin, "Quantitative morphological descriptors confirm traditionally classified morphotypes of Tamarindus indica L. fruits," Genetic Resources and Crop Evolution, vol. 58, no. 2, pp. 299-309, 2011.

[6] P. K. Jaiwal and A. Gulati, "In vitro high frequency plant regeneration of a tree legume Tamarindus indica (L.)," Plant Cell Reports, vol. 10, no. 11, pp. 569-573, 1991.

[7] K. El-Siddig, H. P. M. Gunasena, B. A. Prasad et al., Tamarind, Tamarindus indica L., Southampton Centre for Underutilised Crops, Southampton, UK, 2006.

[8] A. Kalinganire, J. C. Weber, A. Uwamariya, and B. Koné, "Improving rural livelihoods through domestication of indigenous fruit trees in the parklands of the Sahel," in Indigenous Fruit Trees in the Tropics: Domestication, Utilization and Commercialization, F. K. Akinnifesi, R. R. B. Leakey, O. C. Ajaui et al., Eds., pp. 186-202, CABI, 2007.

[9] M. K. Alam, N. A. Siddiqi, and S. Das, Fodder Trees of Bangladesh, Bangladesh Forest Research Institute, Chittagong, Bangladesh, 1985.

[10] S. S. Parvez, M. M. Parvez, E. Nishihara, H. Gemma, and Y. Fujii, "Tamarindus indica L. leaf is a source of allelopathic substance," Plant Growth Regulation, vol. 40, no. 2, pp. 107-115, 2003.

[11] S. S. Parvez, M. M. Parvez, Y. Fujii, and H. Gemma, "Allelopathic competence of Tamarindus indica $\mathrm{L}$. root involved in plant growth regulation," Plant Growth Regulation, vol. 41, no. 2, pp. $139-148,2003$.

[12] S. S. Parvez, M. M. Parvez, Y. Fujii, and H. Gemma, "Differential allelopathic expression of bark and seed of Tamarindus indica L.," Plant Growth Regulation, vol. 42, no. 3, pp. 245-252, 2004.

[13] S. Ushanandini, S. Nagaraju, K. H. Kumar et al., "The antisnake venom properties of Tamarindus indica (leguminosae) seed extract," Phytotherapy Research, vol. 20, no. 10, pp. 851-858, 2006.

[14] P. Siddhuraju, "Antioxidant activity of polyphenolic compounds extracted from defatted raw and dry heated Tamarindus indica seed coat," LWT-Food Science and Technology, vol. 40, no. 6, pp. 982-990, 2007.

[15] R. M. Havinga, A. Hartl, J. Putscher, S. Prehsler, C. Buchmann, and C. R. Vogl, "Tamarindus indica L. (Fabaceae): patterns of use in traditional African medicine," Journal of Ethnopharmacology, vol. 127, no. 3, pp. 573-588, 2010.

[16] M. A. Alam, M. A. Matin, M. M. Hoque, and A. T. M. R. Hoque, "Seed morphology and germination of Ipil Ipil (Leocaena 
leococephala (Lam.) De Wit.) under different conditions at nursery stage in Bangladesh," Asian Journal of Plant Science, vol. 4, no. 2, pp. 98-101, 2005.

[17] M. S. Azad, R. K. Biswas, and M. A. Matin, "Seed germination of Albizia procera (Roxb.) Benth. in Bangladesh: a basis for seed source variation and pre-sowing treatment effect," Forestry Studies in China, vol. 14, no. 2, pp. 124-130, 2012.

[18] M. S. Khan and M. K. Alam, Homestead Flora of Bangladesh, Forestry Division, Bangladesh Agricultural Research Council (BARC), Dhaka, Bangladesh, 1996.

[19] S. K. Kundu and P. M. A. Tigerstedt, "Geographical variation in seed and seedling traits of neem (Azadirachta indica A. JUSS.) among ten populations studied in growth chamber," Silvae Genetica, vol. 46, no. 2-3, pp. 129-137, 1997.

[20] W. J. Wright, Introduction to Forest Genetics, Academic Press, New York, NY, USA, 1976.

[21] A. Loha, M. Tigabu, D. Teketay, K. Lundkvist, and A. Fries, "Provenance variation in seed morphometric traits, germination, and seedling growth of Cordia africana Lam," New Forests, vol. 32, no. 1, pp. 71-86, 2006.

[22] R. Z. Callaham, "Provenance research: investigation of genetic diversity associated with geography," Unasylva, vol. 18, no. 2-3, pp. 40-50, 1964.

[23] M. S. Azad, "Observations on bud burst phenology in a field trial established with Poplar (Populus spp.)," Forestry Studies in China, vol. 14, no. 4, pp. 251-259, 2012.

[24] R. K. Arora, "Genetic diversity and ethnobotany," Neem Research and Development, vol. 3, pp. 33-37, 1993.

[25] M. A. Matin and R. L. Banik, "Effect of polybag size on growth of some forest tree seedlings of Bangladesh," Bangladesh Journal of Forest Science, vol. 22, no. 1-2, pp. 37-43, 1993.

[26] M. A. Matin and M. H. Rashid, "Seed morphology, germination and seedling survival of Albizia trees in the nursery," Bangladesh Journal of Forest Science, vol. 21, no. 1-2, pp. 40-45, 1992.

[27] C. G. Langlois, L. Godbout, and J. A. Fortin, "Seasonal variation of growth and development of the roots of five second year conifer species in the nursery," Plant and Soil, vol. 71, no. 1-3, pp. 55-62, 1983.

[28] Ø. Hammer, D. A. T. Harper, and P. D. Ryan, "Past: paleontological statistics software package for education and data analysis," Palaeontologia Electronica, vol. 4, no. 1, pp. 1-9, 2001.

[29] I. Aranda, L. Castro, M. Pardos, L. Gil, and J. A. Pardos, "Effects of the interaction between drought and shade on water relations, gas exchange and morphological traits in cork oak (Quercus suber L.) seedlings," Forest Ecology and Management, vol. 210, no. 1-3, pp. 117-129, 2005.

[30] A. Portsmuth and Ü. Niinemets, "Interacting controls by light availability and nutrient supply on biomass allocation and growth of Betula pendula and B. pubescens seedlings," Forest Ecology and Management, vol. 227, no. 1-2, pp. 122-134, 2006.

[31] J. Wang, H. Ren, L. Yang, and N. Liu, "Seedling morphological characteristics and seasonal growth of indigenous tree species transplanted into four plantations in South China," Landscape and Ecological Engineering, vol. 9, no. 2, pp. 203-212, 2013.

[32] S. Azad, M. R. Manik, S. Hasan, and A. Matin, "Effect of different pre-sowing treatments on seed germination percentage and growth performance of Acacia auriculiformis," Journal of Forestry Research, vol. 22, no. 2, pp. 183-188, 2011.

[33] M. Liu, R. Li, and M. Liu, "Adaptive responses of roots and root systems to seasonal changes," Environmental and Experimental Botany, vol. 33, no. 1, pp. 175-188, 1993.
[34] R. W. Zobel, "The genetics of root development," in The Development and Function of Roots, J. Torrey and D. Clarkson, Eds., pp. 261-275, Academic Press, London, UK, 1975.

[35] R. W. Zobel, "Soil environment constraints to root growth," Advance Soil Science, vol. 19, pp. 27-51, 1992.

[36] B. Krishan and O. P. Toky, "Provenance variation in seed germination and seedling growth of Acacia nilotica ssp. indica in India," Genetic Resources and Crop Evolution, vol. 43, no. 1, pp. 97-101, 1996.

[37] M. S. Rajawat, R. Rai, T. Chowdhury, B. V. Jayant, and P. R. Nagora, "Provenance trial of neem at Jodhpur (India)," NeemNews Letter of International Neem Network, vol. 1, no. 1, pp. 1216, 1994.

[38] D. Kumar and N. B. Singh, "Age-age correlation for early selection of clones of Populus in India," Silvae Genetica, vol. 50, no. 3-4, pp. 103-108, 2001.

[39] E. P. Cundall, C. M. Cahalan, and T. Connolly, "Early results of Ash (Fraxinus excelsior L.) provenance trials at sites in England and Wales," Forestry, vol. 76, no. 4, pp. 385-399, 2003.

[40] F. M. Padua, "Juvenile selection of Gmelina arborea clones in the Philippines," New Forests, vol. 28, no. 2-3, pp. 195-200, 2004.

[41] A. Benowicz, R. Guy, M. R. Carlson, and Y. A. El-Kassaby, "Genetic variation among paper birch (Betula Papyrifera MARSH.) populations in germination, frost hardiness, gas exchange and growth," Silvae Genetica, vol. 50, no. 1, pp. 7-13, 2001.

[42] N. G. Mantovan, "Early growth differentiation among Prosopis flexuosa D.C. provenances from the Monte phytogeographic province, Argentina," New Forests, vol. 23, no. 1, pp. 19-30, 2002.

[43] J. Y. Shimizu, L. A. Spence, E. G. Martins, and A. J. De Araujo, "Genetic and phenotypic variations in early growth performances of grevillea trees for use in agroforestry systems," International Forestry Review, vol. 4, no. 2, pp. 128-132, 2002. 

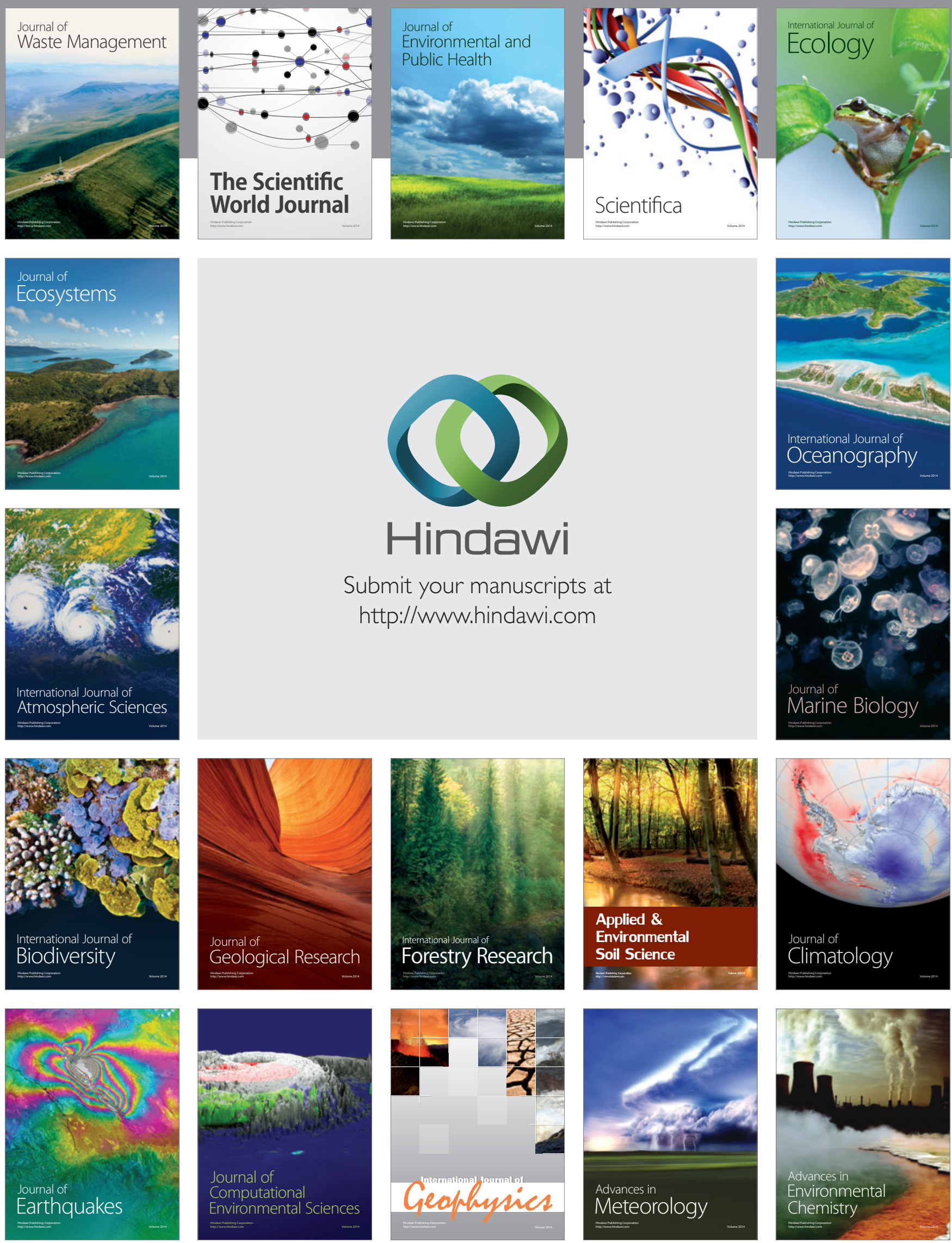